\title{
Hold-up in Ventures for Technology Transfer
}

\author{
Klaus Spremann ${ }^{1}$
}

Swiss Institute of Banking and Finance, School of Finance, University of St. Gallen, Switzerland

\begin{abstract}
Entrepreneurs and Investors found ventures for transferring technology and bringing it closer to the market. Focussing on a situation in which the investor exercises hold-up at the disadvantage of the entrepreneur, this paper works on three points: We identify (1) conditions which make hold-up possible, and discuss (2) measures which help entrepreneurs to protect themselves against hold-up. (3) The balance of powers in a venture is related to returns to scale. Overall, the paper contributes to the theory of small-seized firms which are exposed to high uncertainties including behavioural opportunism.
\end{abstract}

Keywords: Agency theory, hold-up, incomplete contracts, innovation, entrepreneur, knowledge, investor, technology risk, two-sided markets, venture risk.

\section{INTRODUCTION}

The organisation for developing and transferring new technologies is a venture formed by two parties. To put it simply, one is the entrepreneur, the other the investor. The entrepreneur brings her know how into the venture and further develops the technology. The investor brings funding, takes rights, and eventually may commercialise the technology. So, after a certain period of time, the transfer of the new technology is carried out [1]. Although the two mentioned partners of the venture offer different inputs, possess diverse comparative advantages, and have different intentions and preferences, their collaboration can work very well as many successful ventures show.

But a venture is exposed to opportunistic behaviour exercised by one of the two partners. At times, one of them actually acts more for own benefit and against what the partner expects or what had been negotiated. The literature is paying considerable attention to visible or hidden selfishness of the agent, entrepreneur, or manager of the venture. The agent "steels" some of the funds (brought in by the investor) to enhance her own perks, for more easiness on work, or for additional benefits of her team. This type of opportunistic behaviour has found considerable consideration in the literature on the separation of ownership (investors) and control (management) in the modern corporation. Manager's opportunism may prevail in particular in larger firms. The literature originated with [2], [3], [4], [5], [6]. As Gompers and Lerner put it: "information problems ... permit opportunistic behaviour by entrepreneurs after financing".

Not so much analysed is the possibility that the principal or investor is acting in a way which the entrepreneur perceives as "unfair". This type of opportunistic behaviour depicts the investor as "steeling" the technology to circumvent a proper and fair remuneration of the entrepreneur who provided her know how to the venture. This "theft of know how" is realised by the investor through grasping more control and

\footnotetext{
${ }^{1}$ Address correspondence to this author at the University of St. Gallen, School of Finance, Swiss Institute of Banking and Finance, Rosenbergstr 52, 9000 St. Gallen, Switzerland, tel.: +41 71224 70 00, fax: +4171 22470 88, E-mail: klaus.spremann@unisg.ch. The author thanks two anonymous referees for their helpful suggestions on a previous version.
} 
drawing more rights out of the venture as negotiated at the expense of the entrepreneur. Either immediately or after some time the entrepreneur realises that she had given away too much know how for the mere expectation of an appropriate remuneration. The selfish act of the investor is hold-up [7], [8], [9]. While in larger corporations economic, formal and legal structures help to reduce this type of behavioural risk, these structures are not fully developed in ventures and in small-seized firms which are exposed to uncertainties which are typical for intermediate technologies.

The present paper analyses opportunistic hold-up exercised by the investor in such small-sized firms. We explore conditions under which the balance of powers within a venture favours the investor. Our main finding is twofold. First, the investor gets more room for hold-up against the entrepreneur if the latter brings in her full know how already at the beginning. Accordingly, the investor gets fewer options for holdup if the technology will only be developed within the venture during the time period of collaboration. Second, the returns to scale related to the technology have a strong impact on any possibilities for hold-up exercised by the investor to the disadvantage of the entrepreneur. If improving and developing the technology shows decreasing returns to scale, the balance of power within the venture is shifted in favour of the investor. If returns to scale are increasing, the entrepreneur is better hedged against selfish attitudes of investors. These two results are not only valid at the beginning stage of the innovation chain, but at all stages of the process, beginning from invention, over innovation, certification of products, marketing, till imitation.

The remainder of the paper is organised as follows: Section 2 positions the paper with respect to the literature. Section 3 explains why the risk inherent in a new technology requires a venture organisation. Section 4 focuses on venture risk as a second type of risk. Section 5 provides a concrete example of hold-up exercised by an investor who takes more control rights and more claims than originally negotiated. Section 6 shows that the dynamics in which the know how is put into the venture or developed within the venture decides on how much the entrepreneur is exposed to hold-up. Section 7 generalises from the entrepreneurinvestor relationship to the other transfers of technology at the different stages. Section 7 shows why the balance of powers between the party which sells and the party which buys new technology is depending on the return to scale. Section 8 is the conclusion.

\section{REVIEW OF THE LITERATURE}

Innovation is understood as the "application of better solutions that meet new requirements, unarticulated needs, or existing market needs" and it is "accomplished through more-effective products, processes, services, technologies, or business models that are readily available to markets, governments and society [10]. This definition already shows that innovation demands a chain of successive activities such as invention, brainstorming, market observation, design, experimentation, construction, production, market introduction, sales, after sales services. In most innovation chains, these activities are performed by different specialists, and each specialist, after having added work, is transferring what must be seen as an intermediate state of product to another specialist who takes over [11]. Among the intermediate state of products are plans and formulae, prototypes, products before tests and products after tests [12]. Over the successive stages, the intermediate technology come closer and closer to commercialisation. But since the financial realisation only happens at the end of the innovation chain, financing the activities at the stages before is necessary. So at each of the specialised stages within the innovation chain, an "entrepreneur" and an "investor" must collaborate [13].

This collaboration is characterised by uncertainty, several factors of external risk, and consequently by low and unevenly distributed information between the entrepreneur and the respective investor [11], 
[1]. Thus, opportunistic behaviour may add to the external risk factors and uncertainties. The literature focuses on opportunistic behavior of the entrepreneur at the disadvantage of the investor [3], [13]. Thus, protection of the investor is required [14], [15]. In fact, evidence underlines the possibility of opportunism of managers against investors in particular in larger corporations.

Here we focus on opportunistic behaviour which the investor exercises at the disadvantage of the entrepreneur. A case study illustrates that this direction of asymmetry is more likely in small ventures than in larger firms. The dominant form of this direction of opportunism is hold-up [7], [8], [9]. The paper works on three points: First, we identify conditions which make hold-up exercised by the investor of a venture possible. Second, we discuss measures which help entrepreneurs to protect themselves against investor's holdup. Third, we relate the balance of powers in a venture with returns to scale. In particular we show that the balance of powers between entrepreneur and investor depend on the comparative economies of scale their respective activities show. This explains why investors are most powerful in network economies. Overall, the paper works on the theory of ventures and of small-seized firms which are exposed to high uncertainties.

\section{VENTURES and SMALL-SIZED FIRMS IN HIGHLY UNCERTAIN ENVIRONMENTS}

In rare cases one single person invents, innovates, produces, markets a new idea and even manages aftersales customer services. A contemporaneous example is Mark Zuckerberg, founder of Facebook. A historic example for such a vertical-integrated universality was Thomas A. Edison, great inventor and successful businessman. But specialisation along with disintegration of the innovation chain generate economic advantages [16]. As a rule the various steps in which new technology will be created, developed, imitated and turned to products are performed by different persons, firms and organisations. The relay involves several runners, each of whom is focused on one stage within the long chain of innovation.

Consequently, there are several interfaces where research ideas, blueprints, construction plans, intermediate products, or prototypes are transferred from one to another party. At each of these interfaces, two parties collaborate in giving and taking the technology. One party, we call her A, works on the technology, and either immediately or after some time, transfers her work and her know how to another party which takes over. The latter, we call this second-coming party B, pays for assuming rights to use and to commercialise the technology. Party B certainly will have an improved ability to screen, to assess chances, and to utilise networks. This will help $B$ to move the technology closer to the final product market. Party A initially possesses the technological knowledge and works to deepen it, B possesses comparative abilities to use networks and markets.

In simple terms: At each of the interfaces, A sells technology to B. But there are notable differences to a sale of a commodity in a perfect market. In ideally functioning markets, the quality of the traded commodity is high and equally known by all market participants. There are no doubts regarding clearing, settlement, and the execution of the transaction. Further, transactions can happen in a moment, like cash and carry. Finally, the price in a perfect market fulfils all aspects of fairness. In contrast, the qualities of a new technology (research idea, construction plan, prototype, certificated products) bear considerably informational imperfection. Moreover, the little information is often not evenly distributed among interested persons. This ascertainment is obvious for the earlier stages within the chain of technology transfer. But even a technically functioning prototype still faces legal risks and the product is exposed to uncertainties regarding the acceptance by key adopters and end users. Cash and carry transactions are not appropriate for the transfer of technology. Rather than that, the parties who have an interest in giving and taking a new technology must consider a longer period of time for the transfer. Time is required to identify relevant risk fac- 
tors, to share risks and to acquire more information [17]. Time also facilitates defining a fair distribution among the partners. The institutional frame for such a period of learning, sharing, informing and for defining fairness is a venture: Party A brings in know how and continues to perform and to deepen technological work, while party B provides funds and screens opportunities for a later commercialisation. Thus, A brings knowledge into the venture, B capital. Although different in their respective inputs and comparative advantages, the partners share risks, information, and chances.

\section{VENTURE RISK AS BEHAVIOURAL RISK}

Know how as well as money are two resources which exhibit high plasticity [18], [19], [20], [21]: The resources may be formed and used for a wide bunch of purposes. Who uses a resource with high plasticity commands considerable degrees of freedom. In contrast, resources with low plasticity (such as special purpose devices) can only be used in very specific ways. Users of a resource with low plasticity have no freedom to choose what to do and how to do it, the required monitoring and control of the user may thus be minimal: The device already exercises the required control. Since know how and money are both resources with high plasticity, the discretionary freedoms with know and with money are immense. Even if the user of these resources is exposed to a certain degree of monitoring and surveillance, the person will always retain some discretionary room and will not completely be bound to a negotiated and contracted behaviour. Resources with high plasticity thus enable egoistic and opportunistic behaviour, and they also help to mask weaknesses if expertise is lacking.

Partners A and B bring knowledge and capital into the venture and put these resources with high plasticity under their common control. Independent of which weight was given to formal rules and which weight consequently have implicit expectations, the degrees of plasticity of the two resources always leave some room for selfish action. Partner A may find occasions to deceive B, and B also could misplay at the disadvantage of $A$. Such opportunism could neither happen in a perfect market nor if the collaboration were related to resources of low plasticity.

The possibility of opportunistic behaviour creates an additional uncertainty within the venture. This "venture risk" adds to the "technology risk." Accordingly, the technology transfer is characterised by two types of uncertainty. The uncertainty inherent in new technologies requires a venture for the transfer and for the sharing of this technology risk over a certain period of time. The venture however is prone to behavioural risk because know how and money possess high plasticity.

There are certain measures to reduce or even to eliminate venture risk. (1) More detailed contingent contracting among $A$ and $B$ could be combined with improved mutual monitoring. This however is very costly and could destroy mutual trust. (2) Venture risk is also avoided by A and by B if there are prospects of repeating the collaboration on a future occasion. So it is always good to negotiate with partners who have a future. (3) Venture risk is certainly minimised by higher ethical and professional codes, and by a general culture of honesty. This of course narrows the otherwise wider selection of partners.

According to these three measures, many ventures perform well: Partner A brings in her know how, partner $\mathrm{B}$ brings in his funds. The technology risk is well shared within the venture. The well-working partnership allows a further development of the technology and an efficient preparation of a future market success. Both partners show trust and mutual understanding. In several explicit or implicit reviews and negotiations during their partnership, they arrive at honest and fair distributions. Often these splendid ventures convince the partners to repeat their collaboration on future occasions, which again enforces their honesty.

But at times, venture risk is not reduced and does not remain dormant. It is put into effect by one 
or even by both parties. One of the two parties covertly or openly cheats, selfishly exploiting the plasticity of know how or of money. An extensive literature focuses on the separation of ownership and control within corporate entities and analyses the case in which the "manager" or "agent" A behaves opportunistically at the disadvantage of the "investor" or "principal" B. Agent A spends the money of the organisation in a way which benefits herself and her team whereby the principal $B$ has insufficient means to interfere. ${ }^{2}$ Although, in principle, agency theory also applies to situations in which the investor exercises selfish actions against the manager, the literature does not recognise many cases for this direction of opportunism. In particular in large corporations, the typical opportunism is that managers misuse corporate resources at the expense of investors. The reasons why investors in a large corporation typically do not take overt or hidden action against their managers are the size of the organisation and the intention to run it open end. The size of a corporation implies that investors cannot gain substantially by exploiting their managers, and the open-end mode implies that any investors' misbehaviour would make it very costly to find and engage management in the future. This is different (1) in smaller organisations, where an investor could see gains from betraying the manager. Similar cases are (2) organisations which will be terminated, and the investors could see gains by refusing to remunerate the manager. Thus there are two reasons why ventures, founded to facilitate the transfer of technology over a certain period of time, are prone to investor's opportunism. To exercise this opportunism, investor $B$ will try to gain more and faster control over the know how and to retard the remuneration of the inventor, researcher, entrepreneur, or innovator $A$.

\section{CASE STUDY}

For several years $\operatorname{Dr} A$ held a research position in a middle-sized biotech firm in Switzerland. Her expertise and achievements were widely acknowledged and she was directly reporting to the CEO. Some day she made a discovery in an area which was not directly related to her assigned field of work, and one could consider her findings as private intellectual property. Of course, her finding required further studies and experiments such that the imperative was to build a team. At first $\operatorname{Dr} A$ was pondering about leaving her position to start an own company. But then she became aware of her missing experience in legal and financial affairs and that it would be difficult to support a team with own means. So she approached the CEO, told about her finding and suggested to set up a new field of research within the biotech firm. Dr A offered to take the leadership, and she expressed her hope to get compensation for her intellectual property.

The CEO recognised the chances of the finding and perceived the potential of diversifying and enlarging the biotech firm. For several reasons, the CEO envisaged to found a subsidiary in Singapore with the scope of research and experimentation. $\operatorname{Dr} A$ became the founding director of this subsidiary, called IGS Pte Ltd. The company issued one share which was held by the Swiss biotech firm, and Dr A could gain from high

\footnotetext{
2 The relationship between agent A and principal B may be classified according to the kind of the asymmetry in information and control. (1) Most common is moral hazard (hidden action), in which the adverse actions of the agent can never be fully identified by the principal B. Moral hazard is important in management, banking and insurance [23]. The theory of principal-agent-relationships recommends a combination of closer monitoring and the design of effective incentives, such that the agent A "internalises" the preferences of B. (2) Problems of another kind may arise in situations in which the principal $B$ is unable to observe the expertise and the abilities of agent $A$ (hidden quality). These situations have been analysed by [24], [25] and others. Signalling as well as self-selection schemes appear to be appropriate. (3) A third type of egoism is called hold-up. Hold-up may result from the impossibility to negotiate and to write contingent contracts which cover all future possibilities. Then, implicit expectations arise where the incomplete contracts leave free of formal rules. Thus, Party A could suddenly switch to a behaviour, which B, according to personal implicit expectations, is seeing as "unfair". Nevertheless the hold-up may not be illegal. Alchian and others have analysed hold-up and recommended to gain ownership of relevant resources (vertical integration).
} 
monthly payments which were meant to compensate for her continued research, for directorship, and for handing over her intellectual property to the IGS Pte Ltd. Dr A hired a team of young researchers. She started to teach her finding and designed experiments. In economic terms, her intellectual property was brought into the subsidiary (which, not to forget, was directed by her).

Of course, the foundation of the IGS became known in business circles. Shortly after inception, a prominent person B living in Singapore approached the CEO of the Swiss biotech firm. He impressed with the various successes he had had in the business world before and offered to open his vast network such that the market recognition of the IGS in Asia would be enhanced. The CEO as well as $\operatorname{Dr}$ A welcomed Mr B and suggested that the IGS establishes an advisory board without being too specific regarding the competence. $\mathrm{Mr} \mathrm{B}$ and two senior employees of the Swiss biotech company became members of the advisory board which was thought to meet once a year.

Shortly thereafter, Mr B began to increase his interest in the work of the IGS. Although there were no arranged meetings of the advisory board, he started to visit $\operatorname{Dr} A$ and the IGS for talks. Certainly he learned from $\operatorname{Dr} A$ about the schedule of internal meetings in the IGS. Mr B began to show up at internal research seminars and meetings. Mr B continued with his visits of the subsidiary even when the director $\operatorname{Dr} A$ was travelling abroad. He then talked to the team of the IGS and invited the young researchers for lunch. Like the CEO, the researchers were impressed by the talks on the vast network connections of $\mathrm{Mr} \mathrm{B}$, and they began to see him as the person who really would safeguard their jobs in the IGS. Only later $\operatorname{Dr} A$ learned about these visits when she was abroad. And still later $\operatorname{Dr} A$ realised that $\mathrm{Mr} B$ occasionally visited the biotech firm in Switzerland. Mr B then informed the CEO and gave reviews. Somewhat later Mr B urged the CEO to let him preside the advisory board, and $\mathrm{Mr} B$ began to call himself to be nominated as "president" when he was talking in his business circles. The self-appointed president had not only the Swiss CEO but all team members of the IGS on his side who saw promises of a big future for the IGS.

It took only a short wile and "President" B started to criticise Dr A as director of the team and he raised accusations of embezzlement in the IGS. Although the allegations later proved to be false, the standing of $\operatorname{Dr} A$ as director rapidly declined. She terminated her contract, and was replaced by someone who executed the instructions given by "President" B. Things however did not develop well. After some time of mere administering the IGS, the CEO of the Swiss biotech firm realised that $\mathrm{Mr} \mathrm{B}$, however eloquent he always was, never really brought the contacts he spoke of into the Singaporean subsidiary. The IGS became a lame duck, and a year later the rights to use the new technology were sold at modest conditions to another company (with opaque ownership) from where they later found a good market. The CEO, in order not to admit any mistakes, remained full of praise for the events. Dr A found herself without her former position in the biotech firm, directorship of the IGS, intellectual property, and without remuneration.

\section{UNRESISTANT WHO DELIVERS FIRST}

Hold-up exercised by party B in a venture certainly presupposes (1) a certain recklessness, and it also presupposes (2) wide holes in the net of formally ruled rights and duties. Where everything seems to be based on goodwill, understanding, and unspoken expectations, hold-up may happen. But hold-up aims to seize valuables, and where there are no valuables which could be captured, hold-up makes no sense (even if it may be possible because of wide unregulated areas). In a venture meant for technology transfer, the valuables are the resources brought in by the two parties A and B. If one party already put her input into the venture, the other party can try to seize the input. If also the other party brought in the resource, i.e., if both parties have handed their respective inputs over to the venture, certainly one side could start to seize the other in- 
put by hold-up. But the other side could fight back with hold-up alike. Consequently, hold-up will be unlikely (even if there are unregulated areas and if one party is reckless), as long as the attacked side could launch a counter attack. (3) Thus, the only situation in which party B could unilaterally take actions of hold-up is one in which party $A$ already placed her resources into the venture while party $B$ retained his own resources. To sum up: Hold up has three preconditions: (1) Recklessness of one side. (2) Compendious (rather than detailed) formal agreement between the two sides like a term sheet [26]. (3) Payments not matching delivery. This argumentation can easily be verified with the case study. $\operatorname{Dr} A$ brought her intellectual property into the venture with the mere expectation the resource would be there under here sole control. But the few formal rules left wide unregulated rooms. Someone could enter and prepare hold-up. To avoid a counter attack, that person B spoke of bringing own resources into the venture (but actually retained them under his own control).

According to the three preconditions, there are three recipes to avoid hold-up in ventures for technology transfer:

(1) In order to avoid any ruthlessness, the entrepreneur A considers investors only, whose honesty is well-known and who have a reputation for never participating in a power play. As a variant of this recipe to prevent hold-up is to make the party B weak. This can be achieved in four ways. (i) Divide and rule--more equity partners. Several investors are chosen instead of one. (ii) Debt financing--powers to the bank. Use debt financing with strong and reputed debt partners. The capital structure has a strong impact on governance [27]. (iii) Powers to consultants. The third way to diffuse the power of a single investor is to involve counselling and to assign the role of president to a person who is known for making money with advice. (iv) Egoism can also be reduced by negotiating with parties B who are prepared to repeat the partnership on future occasions.

(2) In order to make the holes in the net of formal rules and conditions fine-meshed, the recipe would require to negotiate contingent contracts with many conditions. But this recipe will not always be compatible with the uncertainties inherent in a new technology. Further, it is incompatible with the practice of negotiating term sheets, and finally could give reason for distrust.

(3) In order to match delivery with payments, leave no unpaid valuables lying around in the venture. This obvious recommendation seems to be the most powerful recipe. The entrepreneur must make sure that the venture is providing a pledge on her behalf for all the know how brought into the venture. In our case study, compensation for the know how was arranged as supplement to the monthly salary such that only over a number of years the original intellectual property would have been fully recompensed. But with the early termination of contract the intellectual input of the entrepreneur remained unrewarded. The suggestion for entrepreneurs is to insist on appropriate exit conditions. The conditions of a premature exit of the entrepreneur must guarantee that all input of know how will be fully compensated. The pledge could consist of a golden parachute or of other resources which could be seized such that party $A$ can counter fight hold-up. In practice, this recipe is often overlooked since it appears as if it is the investor who should take care for possible ways to leave the venture. Exit conditions in favour of the entrepreneur force to settle the unpaid part of the value of the know how input, and they set incentives to avoid hold-up.

\section{BALANCE OF POWERS AND ECONOMIES OF SCALE}

Negotiations between entrepreneur and investor (like all deals between two parties) are influenced by the respective powers. Independent of what will be formally written down, a strong partner can easier come 
out on top. Several factors entail a person with power: (1) Power is related to rhetoric ability and excellence in convincing. Power is also related to experience and skill in negotiations. If, for example, the inventor or entrepreneur is working day and night in his garage, speaking only to few folk, while the investor enjoys the exhilarating atmosphere of meetings, seminars, discussions and banquets, it could easily be the case that the investor calls the tune. (2) There is more power where the money is. This law of life means that there is always a certain power bonus favouring the investor. (3) Power has the party which could more easily walk away. Consequently, the distribution of factual power in a venture depends on further opportunities either the entrepreneur or the investor may have. Typically the side with more viable alternatives can gain more rights in negotiations and keeps more freedom during the venture, and at times can even ignore what is written in the contract.

Who has alternatives to contract elsewhere may be one of the coincidental particularities of the situation. So, the entrepreneur could know a number of other investors who equally liked to finance the venture. Similarly, it could be the case that the entrepreneur must move forward and desperately wishes that the investor agrees. On the other side, an investor may be in talks with several entrepreneurs who make offers. This investor could easily compare the prospective values of the offered technologies. In essence, there is a set of competing persons offering know how and (intermediate) technology, and there is a certain group of investors who all are prepared to offer funds in exchange of rights to turn the technology to profit. In other words there is a "market" for intermediate technologies, although it will be far from perfect. It resembles a two-sided market [28], [29].

If there is only one or if there are very few entrepreneurs but many investors, the balance of powers between the two sides favours the one or the few entrepreneurs. If there are many entrepreneurs but only one or a few investors, any of the many entrepreneurs will be less powerful. The balance of power between entrepreneur and investor depends on the form of the aforementioned market. The theory of industrial organisation [30] argues that the form of the market depends on the degree to which economies of scale characterise the production and distribution of the commodities traded. ${ }^{3}$ Thus, the balance of powers between an entrepreneur A and an investor B depend on the "market form" in which they contract and run their venture. And the market form in turn depends on any increasing or decreasing returns to scale. The question is, which are the activities that could exhibit returns to scale.

In a venture, which substitutes the aforementioned "market" between entrepreneurs and investors, two types of activities are relevant. One is the activity of the entrepreneur A: inventing, learning, deepening know how, designing experiments, constructing prototypes. The other activity is what the investor B does: networking, finding prospective buyers, convincing firms who could buy the intermediate technology for the further steps in the innovation chain. Both types of activities have their respective returns to scale. If there is more easiness to grow on the side of A, the entrepreneur would have more powers "in the market" (called venture). If there is more easiness to grow on the side of investor $B$, he would have more powers in the venture.

Typically the activity of A does not exhibit large economies to scale. Having an idea does not make it

\footnotetext{
${ }^{3}$ Returns to scale describe the "easiness to expand". If the technology of a firm shows increasing returns to scale, the costs for the required inputs augment to a lesser degree when the quantity of the output is enlarged. In this sense, the firm can grow in size with easiness. Increasing the scale of the firm can be done with tail wind. Contrary is the situation under decreasing returns to scale. The quantity of inputs and the cost of the firm increase much more than proportional if the output is expanded under decreasing returns to scale. In this sense, growing the firm always happens with contrary wind. Empirical estimations and several reasons in production theory (such as unlisted inputs) show that increasing as well as decreasing returns to scale may govern the production as well as the distribution in the various sectors of industry. Increasing returns to scale lead to bigger and fewer centres of activity and make the single centre more important. Decreasing returns to scale result in a higher number of smaller centres of activity. Any of the many small centres has lesser importance.
} 
easy to have a second idea. Researching and learning are arduous, and guiding a team requires many instructive talks from person to person. The control span remains small in research teams. So economies of scale in working on know how and in improving a technology are very limited. In contrast, the activity of investor B more likely exhibits economies of scale. Networking becomes easier as the network grows in size. If the investor is well-known or commands a label, his standing in the market definitively shows returns to scale. Thus, the economies of scale in the activity of investor B are typically larger than the economies of scale in the activity of entrepreneur A. Consequently, the balance of power within the venture is shifted in favour of investor B. ${ }^{4}$

\section{CONCLUSION}

Advantages of specialisation lead to disintegrated innovation chains (which start with an idea and goes to prototypes, original products and finally to imitation). At certain interfaces, the intermediate technology (such as plans and prototypes) will be transferred from one to another party. At all interfaces, information is low and unevenly distributed. Environmental risks make the intermediate technology highly uncertain. This makes it impossible to execute the technology transfer like a sale in a traditional product market. Rather, at each of the aforementioned interfaces, ventures help to render the technology from the respective "entrepreneur" to an "investor" who takes care of bringing it closer to commercialisation (Section 2). Thus, each venture brings two parties together. One gives the technology and takes remuneration (entrepreneur), the other party takes the technology, finances and later realises the proceeds by approaching the next following interface (investor). All stages of the innovation chain have the same structure. Thus the analysis presented applies to the ventures between entrepreneur and investor in a similar way as it applies to the venture between producer and imitator.

Although most ventures balance the powers of the two partners and work very well, there is risk that one party behaves opportunistically (Section 3). The literature focuses on the large corporation in which managers (agents) may act to their own benefit at the expense of investors (principals). This paper is analysing the other direction of opportunism: Who takes the technology within a venture (investor) may grab more rights than originally negotiated and avoid the full remuneration of the delivering party (entrepreneur). A case study shows how this can happen in practice (Section 4). It is argued that there is more exposure for hold-up if the entrepreneur brings her full know how into the venture at the beginning. Early delivery lowers the resistance to hold-up. Various measures which provide a hedge against opportunism are discussed (Section 5).

The balance of power within a venture also depends on economies of scale. Each venture combines two activities: The entrepreneur works to develop know how and to improve the technology. The investor screens the market and is networking in order to commercialise the (intermediate) technology. Each of these two activities shows a certain degree of returns to scale. Increasing returns to scale lead to bigger and fewer centres of activity and make the few centres more important. Decreasing returns to scale result in a higher number of smaller centres of activity. Then, each of the many small centres is of lesser importance. Thus, within the venture for the technology transfer, the balance of powers depends on the respective re-

\footnotetext{
${ }^{4}$ This observation is in harmony with other industries, where intermediate and no-name products (produced by partner A) are transferred to a corporation $B$ which, after a few minor production steps, distributes under an own label to a huge market of end users. Suppliers and sub-contractors always have limited powers. So, different from a large corporation, where managers may have power and discretion, in small organisations and ventures the balance of powers is typically favouring the investor.
} 
turns to scale of the activities of the entrepreneur (working and developing) and of the investor (networking and marketing). In many cases, the activities of the investor exhibit larger economies of scale. This, again, shifts the balance of power to the disadvantage of the entrepreneur.

\section{CONFLICT OF INTEREST}

The author confirms that this article content has no conflict of interest.

\section{ACKNOWLEDGEMENTS}

Declared none.

\section{REFERENCES}

[1] Lerner J, Leamon A, Hardymon F. Venture Capital, Private Equity, and the Financing of Entrepreneurship. Wiley: 2012.

[2] Berle AA, Means GC. The Modern Corporation and Private Property. Transaction Publisher: New Brunswick 1932.

[3] Alchian AA, Demsetz H. Production, Information Costs, and Economic Organization. AER 1972; 62(5): 777-95.

[4] Holmstrom B. Moral Hazard and Observability. Bell Journal of Economics 1970; 10(1): 74-91.

[5] Fama EF, Jensen MC. Separation of Ownership and Control. Journal of Law and Economics 1983; 26(2): 301-25.

[6] Arrow KJ: Rationality of Self and Others in an Economic System. Journal of Business 1986; 59(4): 385-99.

[7] Alchian AA. Uncertainty, Evolution, and Economic Theory. Journal of Political Economy 1950; 58 (3): $211-21$.

[8] Klein B, Crawford RG, Alchian AA. Vertical Integration, Appropriable Rents, and the Competitive Contracting Process. Journal of Law and Economics 1978; 21(2): 297-326.

[9] Hart O, Moore J. Property rights and the nature of the firm. Journal of Political Economy 1990; 98(6): 1119-1158.

[10] Maryville S. Entrepreneurship in the Business Curriculum. Journal of Education for Business 1992; 68(1): 27-31.

[11] Gompers PA, Lerner J. The Venture Capital Revolution. The Journal of Economic Perspectives 2001; 15(2): $145-68$.

[12] Casson M. The Entrepreneur. An Economic Theory. $2^{\text {nd }}$ ed. Edward Elgar: Cheltenham 2003.

[13] Jensen M, Meckling WH: Theory of the firm: Managerial behavior, agency costs and ownership structure. Journal of Financial Economics 1976; 3(4): 305-60.

[14] Becker GS. Crime and punishment: an economic approach. Journal of Political Economy 1968; 76: 169-217.

[15] Shleifer A, Wolfenzon D. Investor protection and equity markets. Journal of Financial Economics 2002; 66(1): 3-27.

[16] Gompers PA, Kovner A, Lerner J. Specialization and Success: Evidence from Venture Capital. Journal of Economics \& Management Strategy 2009, 18 (3): 817-44. 
[17] Diebold FX, Doherty NA, Herring RJ. The Known, the Unknown, and the Unknowable in Financial Risk Management: Measurement and Theory Advancing Practice. Princeton University Press: Princeton 2010.

[18] Alderson W. Marketing Behavior and Executive Action: A Functionalist Approach to Marketing Theory. Irwin: Homewood 1957, p. 277.

[19] Alderson W, Martin MW. Toward a Formal Theory of Transactions and Transvections. Journal of Marketing Research 1965; 2(2): 117-27.

[20] Williamson OE. Transaction cost Economics: How it works; where it is headed. De Economist 1998; $146: 23-58$.

[21] Williamson OE. The Theory of the Firm as Governance Structure: From Choice to Contract. Journal of Economic Perspectives 2002; 16 (3): 171-195.

[22] Nenonen S, Kjellberg H, Pels J. A new perspective on market dynamics: Market plasticity and the stability-fluidity dialectics. Marketing Theory 2014; 14(3): 269-89.

[23] Arrow KJ. Uncertainty and the welfare Economics of Medical Care. AER 1963; 53(5): 941-73.

[24] Akerlof G. The market for lemons: quality uncertainty and the market mechanism. Quarterly Journal of Economics 1970; 85: 488-500.

[25] Spence M. Signaling in Retrospect and the Informational Structure of Markets. AER 2002; 92(3): 434-59.

[26] Feld B, Mendelson J: Venture Deals. Wiley 2013.

[27] Myers SC: Capital Structure. Journal of Economic Perspectives 2001; 15(2): 81-102.

[28] Caillaud B, Jullien B. Chicken and Egg; Competing Matchmakers. Rand Journal of Economics 2003, 34(2): 309-28.

[29] Jeon DS, Laffont JJ, Tirole J. On the “Receiver Pays" Principle. Rand Journal of Economics 2004; 35: 85-110.

[30] Rochet JC, Tirole J. Platform competition in two-sided markets. Journal of the European Economic Association 2003; 1(4): $990-1029$. 